\title{
Quantifying Spatiotemporal Change in Landuse and Land Cover and Accessing Water Quality: A Case Study of Missouri Watershed James Sub-Region, North Dakota
}

\author{
Papia F. Rozario' ${ }^{1}$ Peter Oduor ${ }^{2 *}$, Larry Kotchman³, Michael Kangas ${ }^{4}$ \\ ${ }^{1}$ Environmental and Conservation Sciences, North Dakota State University, Fargo, ND, USA \\ ${ }^{2}$ Department of Geosciences, North Dakota State University, Fargo, ND, USA \\ ${ }^{3}$ North Dakota Forest Service, Molberg Forestry Center, Bottineau, ND, USA \\ ${ }^{4}$ North Dakota State University, Fargo, ND, USA \\ Email: Papia.Rozario@my.ndsu.edu, ^Peter.Oduor@ndsu.edu, Larry.Kotchman@ndsu.edu, Michael.Kangas@ndsu.edu
}

How to cite this paper: Rozario, P.F., Oduor, P., Kotchman, L. and Kangas, M. (2016) Quantifying Spatiotemporal Change in Landuse and Land Cover and Accessing Water Quality: A Case Study of Missouri Watershed James Sub-Region, North Dakota. Journal of Geographic Information System, 8, 663-682.

http://dx.doi.org/10.4236/jgis.2016.86053

Received: October 8, 2016

Accepted: November 29, 2016

Published: December 2, 2016

Copyright $\odot 2016$ by authors and Scientific Research Publishing Inc. This work is licensed under the Creative Commons Attribution International License (CC BY 4.0).

http://creativecommons.org/licenses/by/4.0/ (c) (i) Open Access

\begin{abstract}
Spatial causal effects on water quality are essential in identification of vulnerable watersheds. Modelling landuse variables is an effective method of projecting localized impairment. This study presents an integrated index, designed to gauge the ability of an 8-digit Hydrologic Unit Code watershed in its ability to produce clean water. This index, $I_{\mathrm{APCW}}$, can be successfully applied on a geospatial platform. In this study we utilized $I_{\mathrm{APCW}}$ to address forest cover dynamics of an impaired watershed, that is, Missouri Watershed James Sub-region in North Dakota. Specific parametric functions were analysed and combined within a customized GIS interface to provide a multi-faceted structured technique to derive $I_{\mathrm{APCw}}$. These included ambient forest cover, housing density, agricultural land, soil erodibility and road density; it can be lucidly ascertained that where a prevailing forest cover undergoes conversion processes, the secondary effect may spur an exponential increase in water treatment costs. These parameters when projected statistically validated temporal and spatial relations of landuse/land cover dynamics to nutrient concentrations especially those that would be noted at the mouth of the watershed. In this study, we found that the levels of Total Dissolved Solids (TDS) were much higher for the years 2014 to 2016 with a discernible increased alkalizing effect within the watershed. When $I_{\mathrm{APCW}}$ was compared to Annualized Agricultural Nonpoint Source (AnnAGNPS), the spatial distribution generated by the AnnAGNPS study showed that fallow areas produced significant amounts of sediment loads from the sub-watershed. These same locations in this study generated a low $I_{\mathrm{APCW}}$.
\end{abstract}




\section{Keywords}

Spatial Analyst, Index of Ability to Produce Clean Water, Landuse, Water Quality

\section{Introduction}

Water and sediment supply, and their management, are critical to many hydraulic project operations. Trend analysis of water quality data is an essential environmental diagnosis of a stream allowing evaluation of how the water body has responded to change in landuse over a period of time. Change in landuse and land cover directly impact sustainable use of reservoirs, water quality, and riparian habitat [1]. However, we are limited by the tools and methodology available to understand the future impacts on a larger scale. Water and sediment supply has been measured only at limited locations and over a limited time period and hence the growing need for predictive models. Sekar and Randhir (2007) developed prioritization maps to characterize conjunctive water harvesting potential that is based on benefits and costs [2]. The results of their study demonstrate that a spatially variable harvesting strategy can be used to minimize runoff loss and to augment water supplies.

Changes in the composition of soil take place due to change in Landuse Land Cover (LULC). LULC is an integrated term that includes both categories of LULC and analysis of changes is of prime importance to understand many social, economic and environmental problems [3]. Landuse (LU) and Land Cover (LC) are the two fundamental components describing the terrestrial environment in relation to both natural and anthropogenic processes [4] [5] [6]. Environmental modifications worldwide are mostly caused due to LU and LC changes, thus it emerges as a key research question [7]. Quantifying landscape patterns enable us to identify and evaluate temporal changes and enable the study of the effects of pattern on ecological processes [8]. Jensen in his investigation of urban landscape perceived landuse as a way by which human beings utilize land while land cover exists as a natural environmental system [9]. Remote sensing and Geographic Information Science (GIS) techniques have been effectively utilized to identify and quantify periodic change in the landscape and its consequent environmental impacts [10]. Land cover is an important parameter for monitoring agricultural, hydrological and watershed modelling which constitute necessary tools for development, planning and management of natural resources in a particular region [10].

Past research has shown that increase in agricultural landuse has direct consequence on sedimentation, nutrients, and pesticides in streams [11] [12]. Landuse change detection is therefore a critical requirement for the assessment of potential environmental impacts and developing effective land management and planning strategies [13]. Surface water bodies are the potential recipients of the contaminations contained in surface runoff from their catchments [14]. This makes surface water quality monitoring an important parameter. There are limited resources available for conservation that can be allocated to the erosion of susceptible areas. These areas can be highlighted through 
mapping, monitoring and prioritizing [15]. Erosion risk mapping of the area can enable decision makers to prioritize susceptible areas for conservation measures in accordance with the level of vulnerability [16]. According to USDA Forest Service, protecting and managing forests in source watersheds is an essential part of future strategies for providing clean safe drinking water. An Index of the Ability to Produce Clean water (APCW) can be generated through GIS overlay Analysis to prioritize impaired watersheds. Spatial Multi Criteria Decision Making (MCDM) has also become one of the most useful methods for landuse and environmental planning, as well as water and agricultural management [17].

The request for GIS models and tools supporting collaborative decisions has increased over the last decade [18]. GIS-based MCDM involves a set of geographically defined basic units (e.g. polygons in vectors, or cells in rasters), and a set of evaluation criteria represented as map layers or attributes. Based on a particular ranking schema, it ultimately informs a spatially complex decision process by deriving a utility of these spatial entities through overlaying the criterion maps according to the attribute values and decision maker's preferences using a set of weights. Therefore, besides criteria selection, criteria weight severely impacts the results of the MCDM [19]. Nutrients in a water body such as nitrogen and phosphorus are considered to be pollutants when these nutrient concentrations become excessive, causing some organisms to proliferate at the expense of others [20]. The situation is significantly multiplied by eutrophication, which is caused by excessive algae growth in a water body from surrounding agricultural watersheds due to the excessive presence of the necessary growth nutrients and ambient conditions that promote algal blooms. This enhanced plant growth reduces the dissolved oxygen levels when the plants decompose, potentially hindering the survival of fish and other aquatic life that depend on pristine conditions [21]. These physical and chemical changes may interfere with the recreational and aesthetic uses of the water body, while both taste and odour problems may make the water less desirable for water supply and human consumption [21]. Thus it is essential to estimate and qualify nutrient contaminations within the watershed. The objectives of this current study were to assess and analyze the LULC changes and to prepare a risk map through weighted overlay of influencing factors such as vegetation, rainfall, LULC, soil data and water quality data. In the process, we also identified the potential areas showing levels of vulnerability to change in soil and water quality.

\section{Description of Study Area}

The sub-basin of the Missouri River spreads over four counties of North Dakota namely Foster, Kidder, Stutsman, and Wells in the Missouri Region-James River Sub-Region [22]. James River, Maple River, Pipestem Creek, Beaver Creek and Spring Creek are located in this sub basin (Figure 1). Pipestem Creek starts from the Pipestem Dam downstream to its confluence with the James River which is about 5.6 miles. The mean annual precipitation is between 13 to 22 inches. Mean Annual air temperature ranges between $37^{\circ} \mathrm{F}$ to $16^{\circ} \mathrm{F}$ for mean elevation ranging from 1280 to 2560 feet. The type of 
soil found at this location is Williams-Bowbells loam which is a well-drained, non-saline clay loam with calcium carbonate of about $20 \%$. Figure 2 shows a part of the watershed near Pingree, North Dakota which was one of the sampling locations. Figure 3 shows a view of the watershed. Riparian forests (Figure 4) are predominant along the rivers.

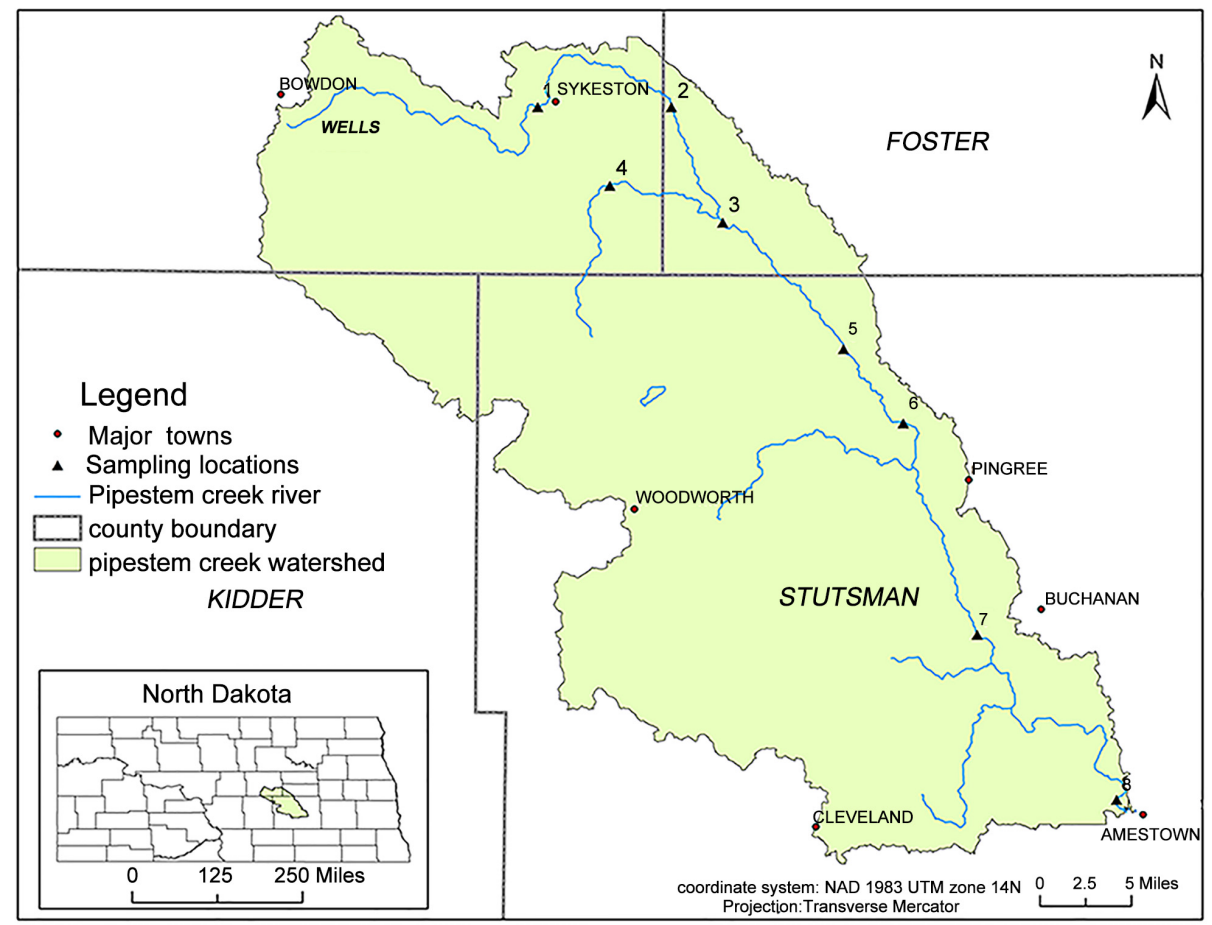

Figure 1. Location of study area-Pipestem Creek in North Dakota, USA showing sampling sites.

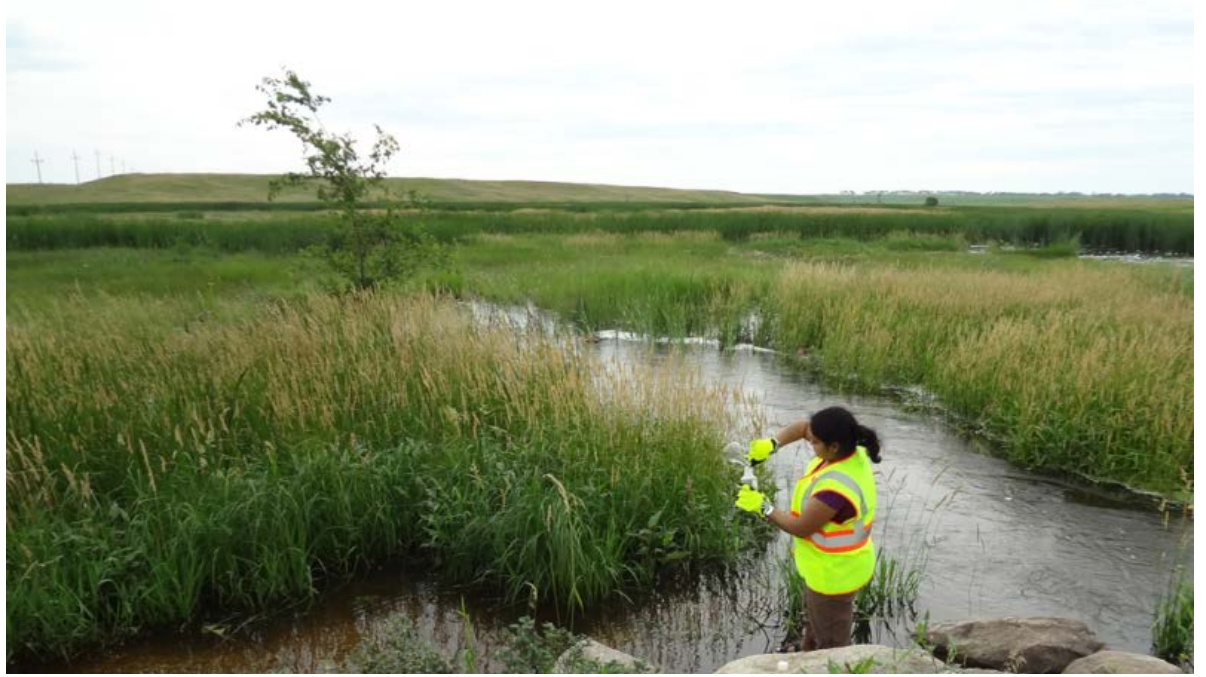

Figure 2. Collecting water samples at the Pipestem Creek. 


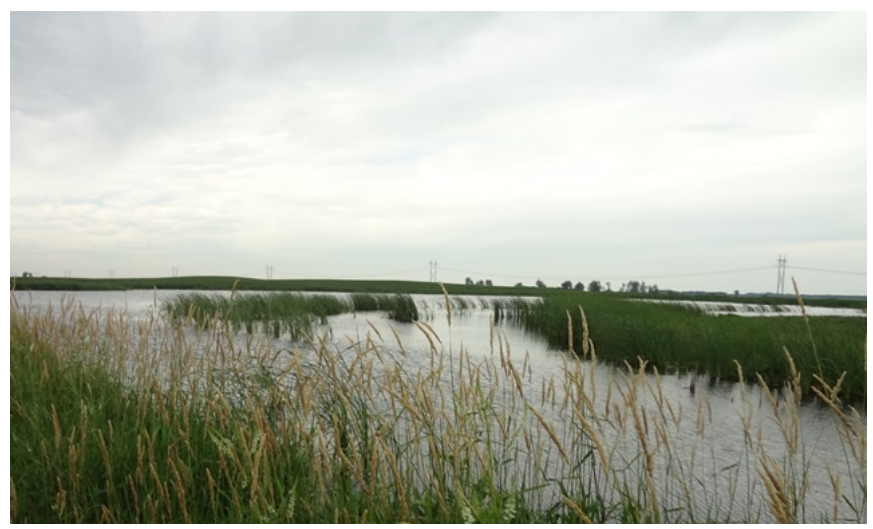

Figure 3. Pipestem Creek near Pingree in North Dakota, USA.

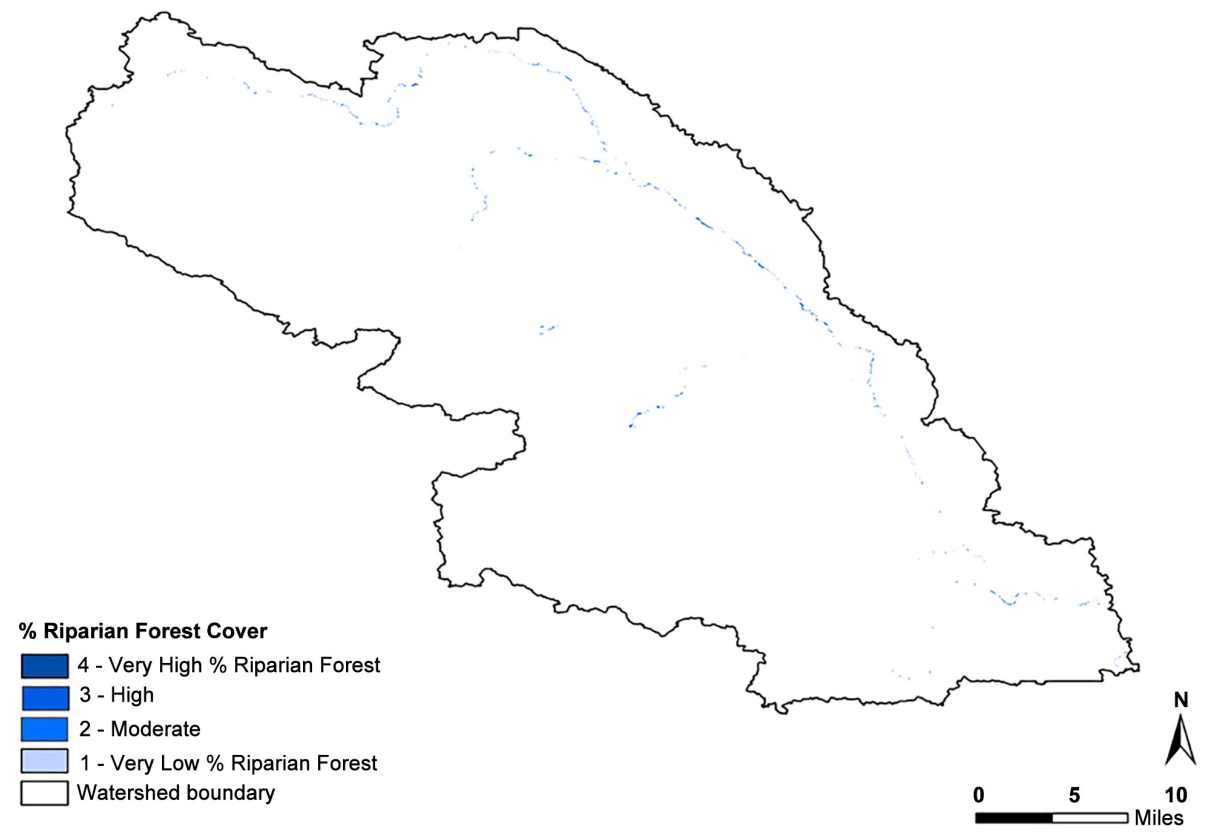

Figure 4. GIS weighted scoring showing percentage change in riparian forests.

\section{Materials and Methods}

\subsection{Data Processing and GIS Analysis}

Historic data of Pipestem Creek was used to perform a spatial analysis and identify localised areas of impairment within the watershed. Forest Cover including riparian forests and agricultural landuse data was acquired from United States Department of Agriculture National Agricultural Statistics Service (NASS). Soil erodibility dataset was acquired from United States Department of Agriculture National Resources Conservation Service (NRCS). Road network data and year 2000 Housing Density data was acquired from the North Dakota GIS Hub. The landuse and land cover was classified us- 
ing the Anderson classification system [23]. NLCD data, a raster dataset, was imported to ArcMap ${ }^{\oplus}$ 9.3, a GIS software, where only the study area was clipped. Each attribute dataset was processed individually to produce a raster grid. To summarize forest cover, the "Tabulate Areas" function was used in ArcMap 9.3, to calculate the acreage of forested land for the watershed. The percent of the watershed that is forested was calculated by dividing the acreage of forested land by the total watershed land acreage [24]. The results were saved to the attribute field of this shapefile which was then converted to a $30 \mathrm{~m}$ raster dataset (Figure 5). The percent forest was reclassified into the four categories (Table 1(a)). Category break points were entered as half integers between the intervals. For example, a value of 24.5 was the break point for percent forest land scored as low or moderate. The results were saved in the corresponding attribute field. Agricultural land was summarized using grid values from the NLCD 2001 dataset of North Dakota. The same method was replicated to tabulate the areas under agricultural land. The percent agricultural land was reclassified into the four categories summarized in Table $1(b)$. Category break points were entered as half integers between the intervals. For example, 30 was the threshold for percent agricultural land scored as low. The results were saved in the attribute field of this shapefile which was then converted to a $30 \mathrm{~m}$ raster dataset (Figure 6). For riparian forest cover, the acreage of riparian forested land was divided by the total acreage of riparian buffer in the watershed. The percent riparian forest cover was reclassified into the four categories summarized in Table 1(c). Category break points were entered as half integers between the intervals. A value of 29 was the break point for percent riparian forest scored as low. The results were saved in the attribute field of this shapefile which was then converted to a $30 \mathrm{~m}$ raster dataset (Figure 4). The North Dakota national roads dataset was split into East

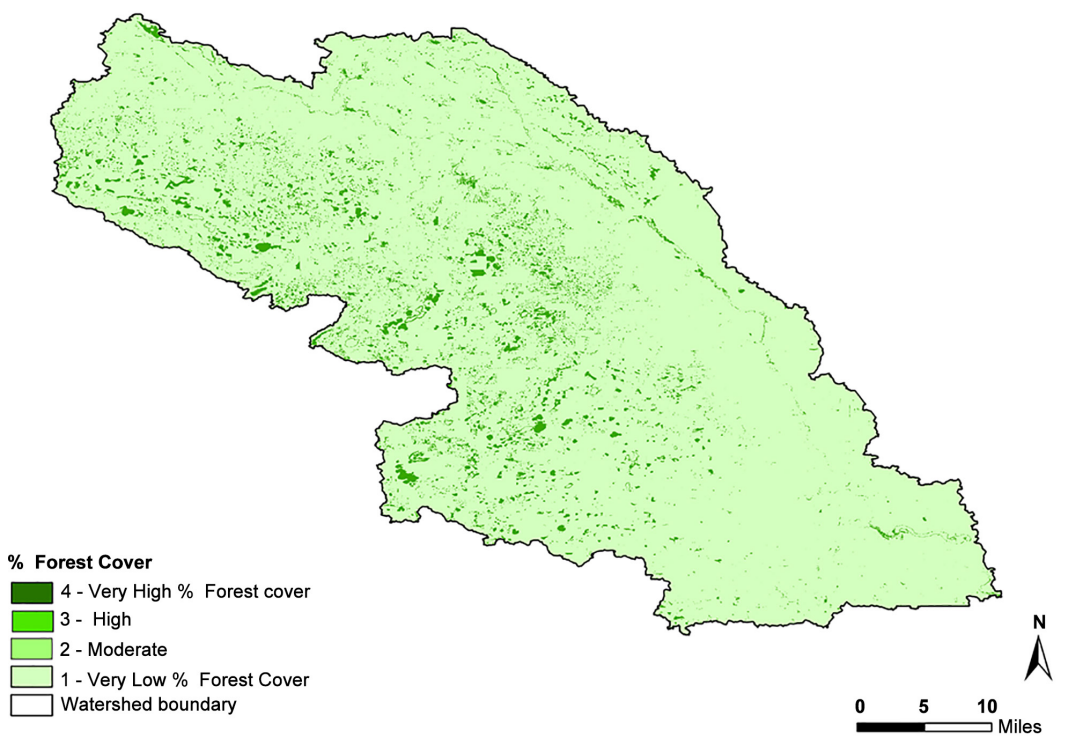

Figure 5. GIS weighted scoring showing percentage change in other forests. 
Table 1. (a) Percent forest cover reclassification; (b) Percent agricultural land reclassification; (c) Percent riparian forest cover reclassification; (d) Road density reclassification; (e) Soil erodibility reclassification; (f) Housing density reclassification.

(a)

\begin{tabular}{ccccc}
\hline \multirow{2}{*}{ Attribute } & \multicolumn{4}{c}{ Rating for 30-meter grid cell } \\
\cline { 2 - 5 } & $\begin{array}{c}\text { Low } \\
(1 \text { point })\end{array}$ & $\begin{array}{c}\text { Moderate } \\
\text { (2 points) }\end{array}$ & $\begin{array}{c}\text { High } \\
\text { (3 points) }\end{array}$ & $\begin{array}{c}\text { Very High } \\
\text { (4 points) }\end{array}$ \\
\hline Percent forest land (F) & $0-24$ & $25-49$ & $50-75$ & $>75$ \\
\hline
\end{tabular}

(b)

\begin{tabular}{ccccc}
\hline \multirow{2}{*}{ Attribute } & \multicolumn{4}{c}{ Rating for 30-meter grid cell } \\
\cline { 2 - 5 } & $\begin{array}{c}\text { Low } \\
(1 \text { point })\end{array}$ & $\begin{array}{c}\text { Moderate } \\
\text { (2 points })\end{array}$ & $\begin{array}{c}\text { High } \\
\text { (3 points })\end{array}$ & $\begin{array}{c}\text { Very High } \\
\text { (4 points })\end{array}$ \\
\hline Percent agricultural land (A) & $>30$ & $21-30$ & $10-20$ & $<10$ \\
\hline
\end{tabular}

(c)

\begin{tabular}{ccccc}
\hline \multirow{2}{*}{ Attribute } & \multicolumn{4}{c}{ Rating for 30-meter grid cell } \\
\cline { 2 - 5 } & Low & Moderate & High & Very High \\
$(1$ point $)$ & $(2$ points $)$ & (3 points) & (4 points) \\
\hline Percent riparian forest cover (R) & $0-29$ & $30-50$ & $51-70$ & $>70$ \\
\hline
\end{tabular}

(d)

\begin{tabular}{ccccc}
\hline \multirow{2}{*}{ Attribute } & \multicolumn{4}{l}{ Rating for 30-meter grid cell } \\
\cline { 2 - 5 } & $\begin{array}{c}\text { Low } \\
(1 \text { point })\end{array}$ & $\begin{array}{c}\text { Moderate } \\
(2 \text { points })\end{array}$ & $\begin{array}{c}\text { High } \\
\text { (3 points) }\end{array}$ & $\begin{array}{c}\text { Very High } \\
\text { (4 points) }\end{array}$ \\
\hline \multirow{2}{*}{ Road density (D, quartiles) } & $75-100$ th & $50-74$ th & $25-49$ th & $0-24$ th \\
& percentile & percentile & percentile & percentile \\
\hline
\end{tabular}

(e)

\begin{tabular}{ccccc}
\hline \multirow{2}{*}{ Attribute } & \multicolumn{4}{c}{ Rating for 30-meter grid cell } \\
\cline { 2 - 5 } & Low & Moderate & High & Very High \\
$(1$ point $)$ & $(2$ points $)$ & (3 points) & (4 points) \\
\hline Soil erodibility (S, k factor) & $>0.34$ & $0.28-0.34$ & $0.2-0.28$ & $0-0.2$ \\
\hline
\end{tabular}

(f)

\begin{tabular}{ccccc}
\hline \multirow{2}{*}{ Attribute } & \multicolumn{4}{c}{ Rating for 30-meter grid cell } \\
\cline { 2 - 5 } & $\begin{array}{c}\text { Low } \\
(1 \text { point })\end{array}$ & $\begin{array}{c}\text { Moderate } \\
(2 \text { points })\end{array}$ & $\begin{array}{c}\text { High } \\
\text { (3 points })\end{array}$ & $\begin{array}{c}\text { Very High } \\
\text { (4 points })\end{array}$ \\
\hline $\begin{array}{c}\text { Housing density } \\
\text { (H, acres per housing unit in 2000) }\end{array}$ & $\begin{array}{c}<0.6 \\
\text { acre/unit }\end{array}$ & $\begin{array}{c}0.6-5.0 \\
\text { acres/unit }\end{array}$ & $\begin{array}{c}\text { acres/unit (east) } \\
\text { acres } / \text { unit }\end{array}$ & (east) \\
\hline
\end{tabular}

and West portions using the county boundary shape files. The "Repair geometry" tool for the east and west roads dataset was used to repair self-intersecting lines. The "multipart to single part" tool on each dataset was used to join multipart lines. Each road shapefile was converted to a coverage arc. A "Simplify Line" tool was run on each 


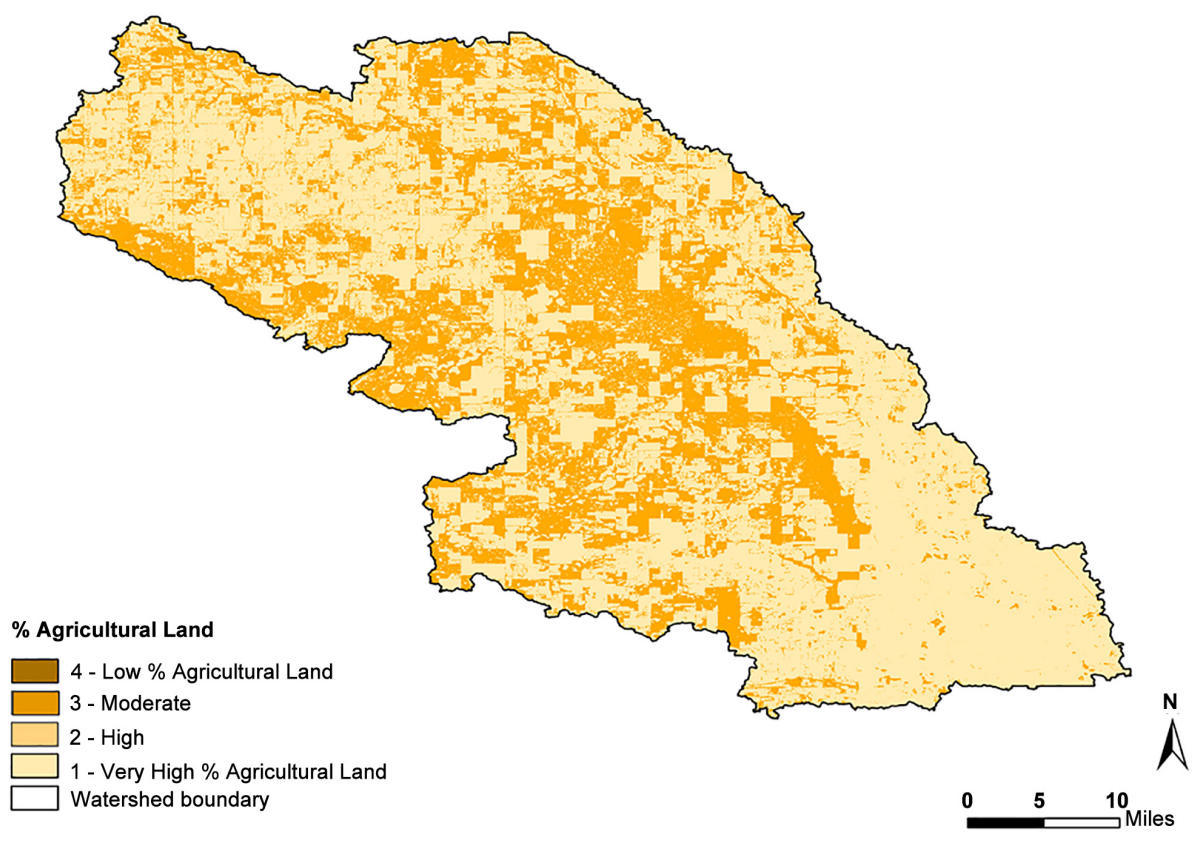

Figure 6. GIS weighted scoring showing percentage of agricultural land.

layer to remove excessive vertices. The simplification tolerance was set to $10 \mathrm{~m}$. A "Line Density" function was applied on each of the resulting coverage. Parameters were set as cell size of $30 \mathrm{~m}$, search radius of $565 \mathrm{~m}$ (to equal a search area of approximately $1 \mathrm{~km}^{2}$ ) and the units were set as square kilometre. Finally, the East and West line density raster was merged into one raster dataset (Figure 7). The results were sorted into four quartiles, and reclassified with values 1 - 4 as shown in Table 1(d). To summarize the soil erodibility map, first, the soil dataset was clipped to the watershed boundary. Then this dataset was converted to a raster format using kffact field as the grid value. The kffact field is the $k$ factor in the soil which contains the erodibility values in the dataset. The grid (Figure 8) was then reclassified as shown in Table 1(e). The raw housing data file was reclassified into 15 classes to reduce the file size. The classification used was based on 2000 US Census Bureau block (SFI) data developed by the Natural Recourse Ecology Lab [24]. Each of the 15 classes was assigned a value range of housing density, for example, class 5 ranged from 32 to 49 . To summarize the housing density data, the raw 2000 housing density data was clipped to the watershed area and resampled from a 100 $\mathrm{m}$ grid to a $30 \mathrm{~m}$ grid (Figure 9 ). The raw grid values in units per hectare were converted to acres/unit using the relation [24]:

$$
((\text { units/ha }) / 1,000) \times 1 \text { ha/2.47 acres }=\text { units/acre }(\text { invert })=\text { acres/unit }
$$

This generated a new reclassified dataset with 15 classes. The 15 value classes were categorised into four housing density classes: rural, exurban, suburban, and urban where rural ranged from 1 to 8 and assigned a reclassified value of 4; exurban was 9 to 
10 assigned a value of 3; suburban was 11 to 12 which was assigned a value of 2 and for the urban class, ranging from 13 to 15 assigned a value of 1 . So the weightage was as-

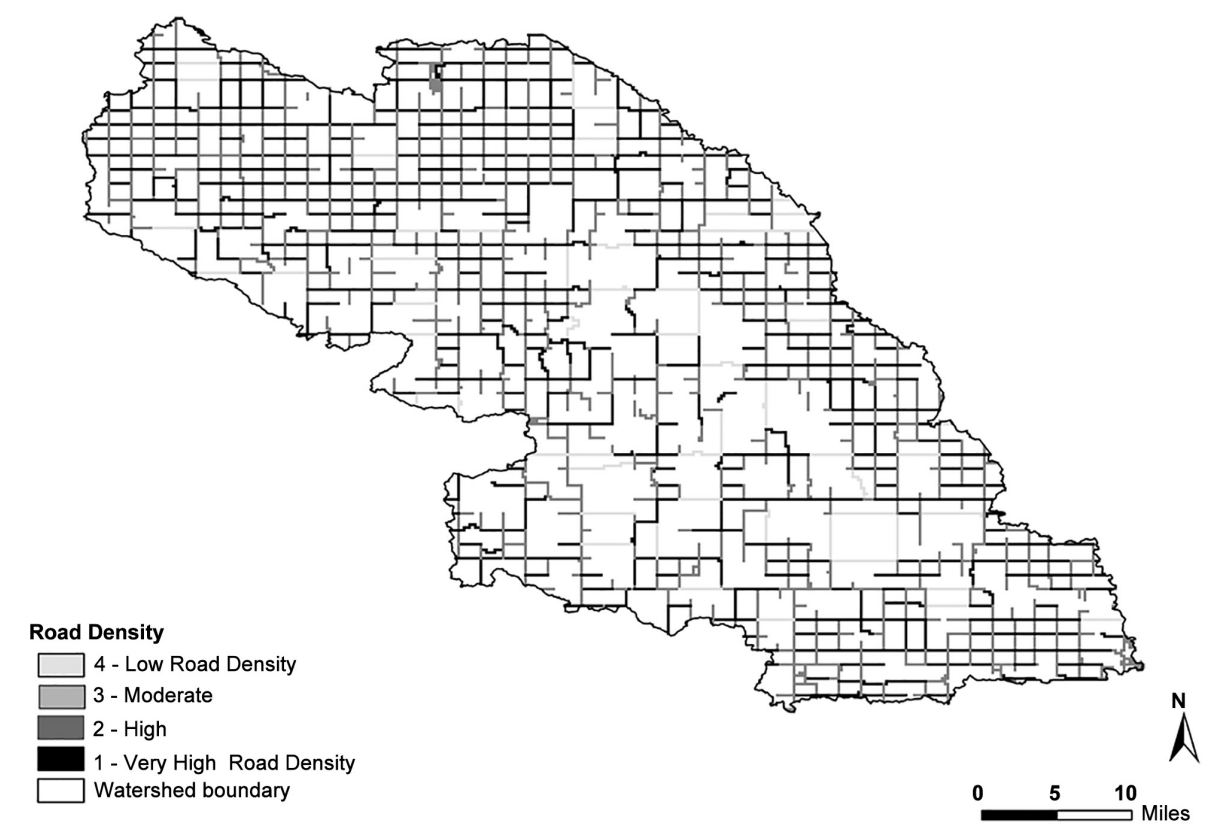

Figure 7. GIS weighted scoring showing percentage of road density.

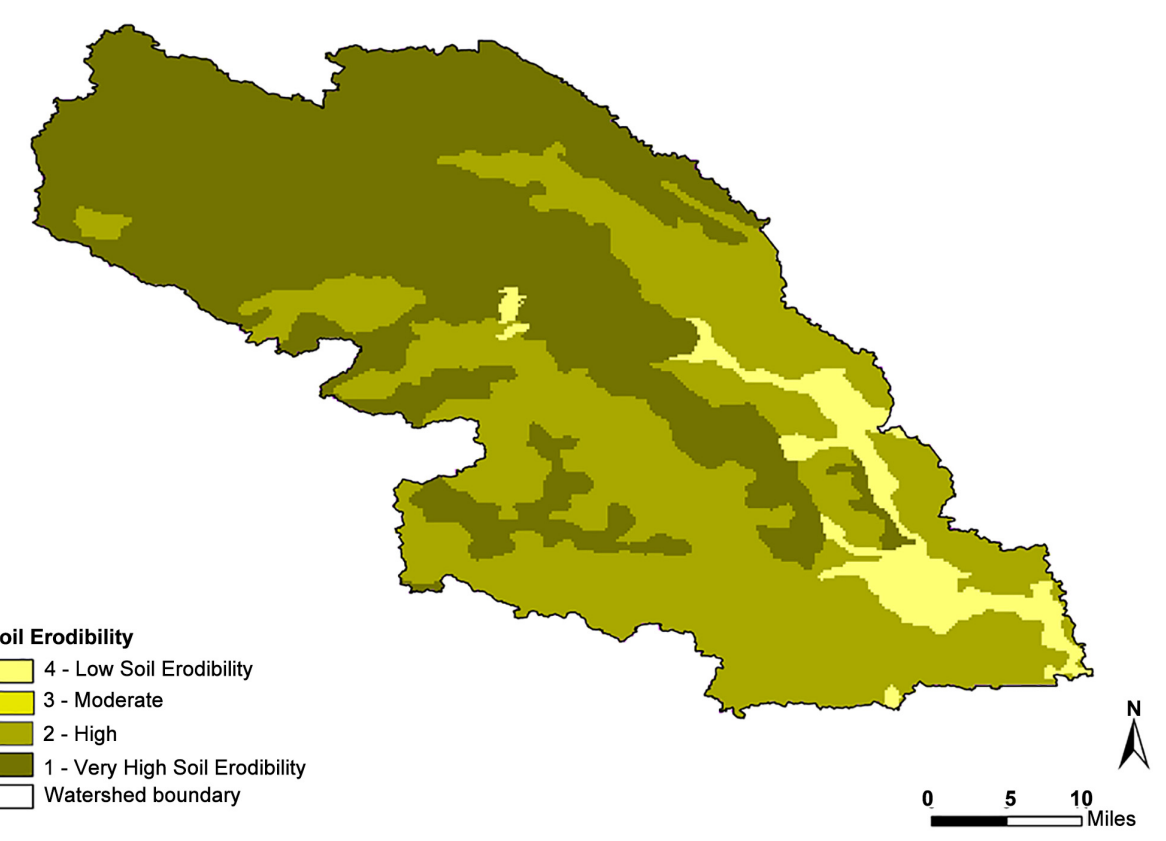

Figure 8. GIS weighted scoring showing soil erodibility. 
signed based on this as shown in Table $1(\mathrm{f})$. Using raster calculator add function for the six rasters, resulted in a grid output with values ranging from 6 to 24 for each $30 \mathrm{~m}$ grid cell. Using ArcMap ${ }^{\oplus} 9.3$ Spatial Analyst, a weighted overlay was done using the data that included forested land, riparian cover, agricultural land suitability, soil erodibility, road density and housing density data. Equation 1 shows the underlying concept in a weighted overlay process [24]:

$$
I_{A P C W}=R+F+S+A+D+H,
$$

where, $F=$ forest land (percent); $A=$ agricultural land (percent); $R=$ riparian forest cover (percent); $D=$ road density (quartiles); $S=$ soil erodibility ( $k$ factor); $H=$ housing density (acres per housing unit in 2000). $I_{\mathrm{APCW}}$ is the Index of the Ability to Produce Clean Water. All the variables were classified into four classes: low, moderate, high and very high. This was done to maintain an equal influence. The weighted overlay tool generated a final raster dataset which was a mean composite score by watershed. Figure 10 shows the map of the study area with the APCW Index. The APCW index was originally used in a study conducted by Barnes et al., in 2009 [24] where the index was generated for watershed at a regional level.

\subsection{Analysis of Soil Data}

Soil samples were collected in 2011 from the top soil layer (0 - 6 inches) to capture leachable ions within Pipestem Creek watershed. The sampling sites were selected such that they incorporated the entire study area. Areas that depicted a low composite score in the map of the $I_{\mathrm{APCW}}$ (Figure 10) were kept under consideration while choosing the sampling points. Soil testing was done to analyze 12 different elements, which included

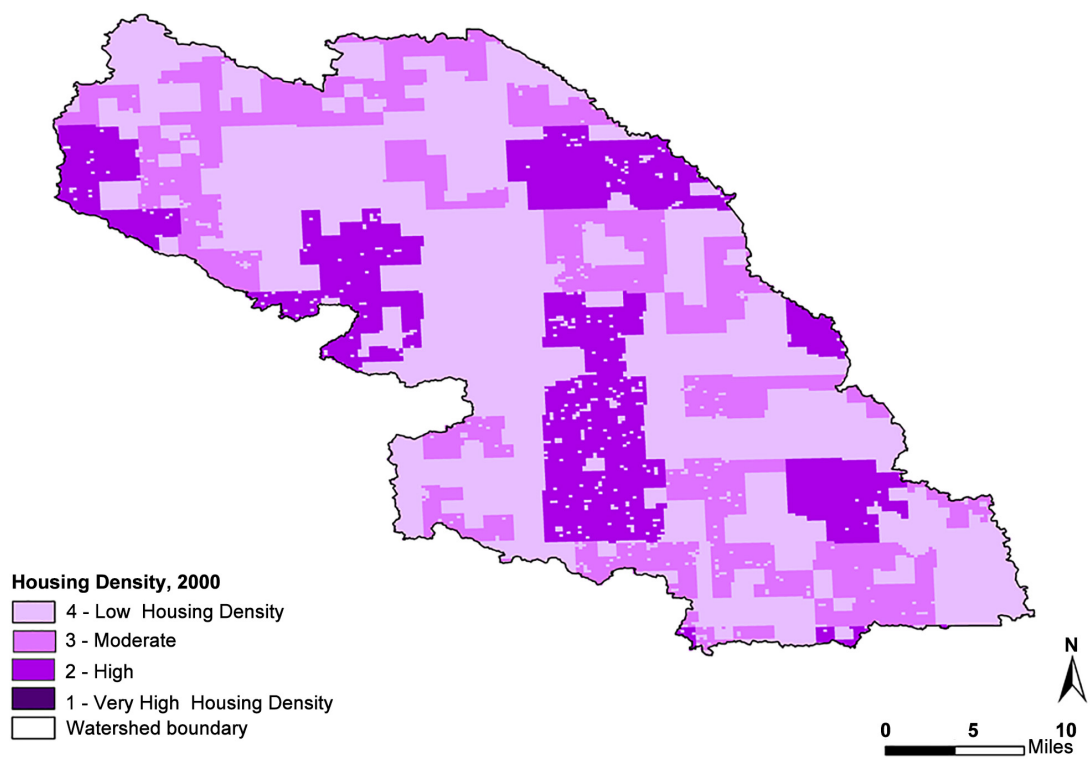

Figure 9. GIS weighted scoring showing percentage of housing density. 


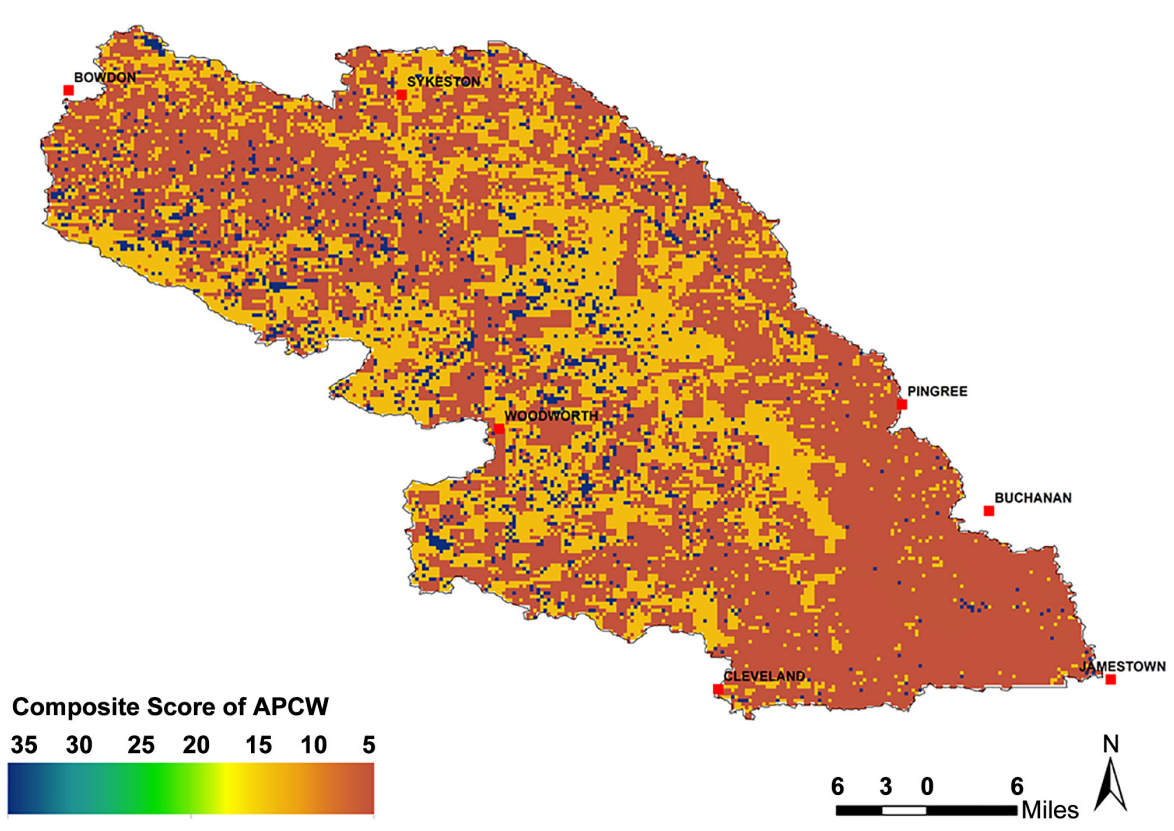

Figure 10. Index of the ability to produce clean water within the study area.

Sodium, Potassium, Calcium, Magnesium, Copper, Chlorine, Nitrate, Phosphate, Zinc, Iron, Manganese and sulphur. Nitrate Electrode Method was used to determine the Nitrate concentration in the soil where $20 \mathrm{~g}$ of the soil sample was added to $50 \mathrm{ml}$ of an extracting solution. The suspension was stirred with a magnetic stirrer and then read on a $\mathrm{pH} /$ ion meter. Chlorides were also estimated using a $\mathrm{pH} /$ ion meter. The Olsen Test was used to detect Phosphorus levels in the soil where the colorimeter is used to produce an intensity and standard curve to determine phosphorus concentration in the soil. Estimates of available Potassium $(\mathrm{K})$ in the soil were done by Atomic adsorption/emission Spectrometer which gives a standard curve for $\mathrm{K}$ by emission. The result was multiplied by 10 to give ppm in a soil $(\mathrm{mg} \cdot \mathrm{K} / \mathrm{kg})$. Estimates of exchangeable calcium and magnesium were also acquired using Atomic adsorption/emission Spectrometer by adsorption and Sodium estimates by emission. Inductively coupled plasma (ICP) was used to measure sulphate levels in solution, as well as organic and inorganic $S$. The advantage of ICP is in its low standard errors [25]. Micronutrients such as Zinc, Iron, Manganese and Copper were estimated using an Atomic absorption spectrophotometer.

\subsection{Analysis of Water Quality Data}

Water samples were collected from 8 different sites along the Pipestem Creek-James sub region of the Missouri river in 2011. Again, areas that depicted a low composite score in the map of the $I_{\mathrm{APCW}}$ (Figure 10) were kept under consideration while choosing the sampling points. These were independently tested in an EPA certified laboratory (Fargo Cass Public Health Environmental Laboratory in North Dakota) using standard 
EPA methods, sound Colorimetric and Ion Chromatography (IC) principles. The EPA 300.0 method [26] was used to analyse Nitrate-Nitrite, Sulphate, Chloride and fluoride amounts in the water. All samples that contained particles larger than 0.45 microns and reagent solutions that contain particles larger than 0.20 microns were filtered prior to any IC analysis. This method involves introducing $2-3 \mathrm{ml}$ of the water sample to an Ion Chromatograph where the anions of interest are separated, measured, using a system comprised of a guard column, analytical column, suppressor device, and conductivity detector. A $1 \mathrm{~mL}$ of concentrated eluent $(7.3100 \times)$ to $100 \mathrm{~mL}$ of each standard and sample was added for presence of negative peaks near the fluoride peak which can usually be eliminated by the addition of the equivalent. The EPA 200.7 method [27] was used to quantify amounts of Calcium, Iron, Manganese, Magnesium, Sodium, Potassium and total hardness. This method involves multi-elemental determinations by an Inductively Coupled Plasma Atomic Emission Spectroscopy (ICP-AES) using sequential or simultaneous instruments. The instruments measure characteristic atomic-line emission spectra by optical spectrometry. SM2320 B Titration Method was used for carbonates, bicarbonates, hydroxides and total alkalinity where a $\mathrm{pH}$ meter was used [28]. This method involves hydrolysis of solutes that react with the addition of standard acid whereas alkalinity would depend on the $\mathrm{pH}$ used. The amount of Total Dissolved Solids (TDS) was analyzed using the SM2540C method where a well-mixed sample is filtered through a standard glass fiber filter, and the filtrate is evaporated till dry in a weighed dish to constant weight at $180^{\circ} \mathrm{C}$. The increase in dish weight represents the total dissolved solids [29].

\section{Results and Discussion}

GIS Weighted Overlay scoring (Figure 10) on a 30-meter grid generated an index that ranked (high to low) the watershed based on its ability to produce clean water. Results generated were primarily driven by affiliated landuse. Areas that are darker with a high composite score from 25 to 30 represent areas within the watershed having a higher ability to produce clean water which corresponds to high riparian cover, high forest cover, low soil erodibility, low agricultural land area, low road density and low housing density. Similarly, areas that are lighter in colour, with a low composite score from 5 to 15 , are areas that have a very low ability of producing clean water corresponding to low riparian cover, low forest cover, high soil erodibility, high agricultural land, high road density and high housing density. This indicates a direct geographic connection between forests, water and people [30]. Forest Cover (Figure 5) on the southern part of the watershed is almost negligible as most of the agricultural fields lie there. This region shows a very low $I_{\mathrm{APCW}}$. The entire watershed has a very low riparian buffer (Figure 4) to protect the streams from the adjacent landuse. Soil erosion ability within the watershed is shown in Figure 8 where the darker areas depict very high soil erosion probability whereas the lighter areas show very low soil erosion probability. Figure 6 shows the percentage of agricultural land. Darker areas signify higher percentage of fallow land whereas lighter areas signify less agricultural practice. Figure 7 and Figure 
9 show housing density and road density information consecutively. These variables do not depict vivid information due to the fact that the study area is predominantly an agricultural watershed with very few residential land and proper metalled roads.

The tables display the data from the water samples collected. The presence of Total Dissolved Solids (TDS) in large amounts ranging from $852 \mathrm{mg} / \mathrm{l}$ to $1020 \mathrm{mg} / \mathrm{l}$ can be seen (Table 2). Higher levels of Sulphate $\left(\mathrm{SO}_{4}\right)$ were seen ranging from $96 \mathrm{mg} / \mathrm{l}$ to 533 $\mathrm{mg} / \mathrm{l}$ (Table 3). Recommended limits of Sulphate in water for water used as a domestic water supply are below $250 \mathrm{mg}$. Although such high levels are not toxic to humans directly, they are an indicator of non-point source pollution within a watershed [31]. Bicarbonates were present in the water ranging from $87 \mathrm{mg} / \mathrm{l}$ to $250 \mathrm{mg} / \mathrm{l}$ in most sites (Table 3). Thus, the total hardness of water was very high ranging from 150 to 500 $\mathrm{mg} / \mathrm{l}$, in turn raising the alkalinity of water. Nitrate, Phosphate and Chloride levels were not significant enough to be reported. The soil samples contained soluble salts such as sodium $\left(\mathrm{Na}^{+}\right)$, potassium $\left(\mathrm{K}^{+}\right)$, calcium $\left(\mathrm{Ca}^{2+}\right)$ and magnesium $\left(\mathrm{Mg}^{2+}\right)$ along with anions chloride $\left(\mathrm{Cl}^{-}\right)$, sulphate $\left(\mathrm{SO}_{4}^{2-}\right)$, nitrate $\left(\mathrm{NO}_{3}^{-}\right)$, bicarbonate $\left(\mathrm{HCO}_{3}^{-}\right)$and carbonate $\left(\mathrm{CO}_{3}^{2-}\right)$. Out of these, Calcium was found in very high levels ranging from 2000 ppm to $2900 \mathrm{ppm}$ followed by magnesium and sodium. Since the watershed is enclosed within agricultural lands, fertilizer residues washed out from the adjoining fields could attribute to these higher levels of nutrients. Agricultural landuses within watersheds have been linked to increased nutrient concentrations in river waters via wastewater, fertilizer use, cultivation of $\mathrm{N}$ fixing crops, and atmospheric deposition [31]. The cation content (Table 4) in water showed presence of calcium ranging from 37 to $87 \mathrm{mg} / \mathrm{l}$, Sodium ranging from 53 to $122 \mathrm{mg} / \mathrm{l}$ and Magnesium ranging from 20 to $68 \mathrm{mg} / \mathrm{l}$ which is not significantly high but they can accumulate leading to a high Sodium Absorption Ratio in the water.

A comparison of the water quality data was done within this study to verify and quantify the water quality data (Table 5(a) and Table 5(b)). Excessive nutrient loading causes eutrophication of lakes and streams [32]. Increased nutrient and algae concentration can lead to water quality problems when these concentrations reduce water

Table 2. In situ water sample data from 8 sampling locations within the study area showing the sediment load.

\begin{tabular}{cccc}
\hline Site Number & $\begin{array}{c}\text { Total Dissolved Solids } \\
(\text { TDS }) \text { mg/l }\end{array}$ & $\begin{array}{c}\text { Total Hardness (TH) } \\
\mathrm{mg} / \mathbf{l}\end{array}$ & $\begin{array}{c}\text { Total Alkalinity (TA) } \\
\mathrm{mg} / \mathrm{l}\end{array}$ \\
\hline 1 & 852 & 474 & 245 \\
2 & 628 & 336 & 163 \\
3 & 1020 & 493 & 292 \\
4 & 408 & 186 & 176 \\
5 & 383 & 206 & 104 \\
6 & 345 & 264 & 62 \\
7 & 637 & 381 & 46 \\
8 & 532 & 310 & 87 \\
\hline
\end{tabular}


Table 3. In situ water sample data from 8 sampling locations within the study area in 2011 showing anion content.

\begin{tabular}{cccccc}
\hline $\begin{array}{c}\text { Site } \\
\text { Number }\end{array}$ & $\begin{array}{c}\text { Nitrate-Nitrite } \\
\text { as N (mg/l) }\end{array}$ & $\begin{array}{c}\text { Phosphate } \\
(\mathrm{mg} / \mathrm{l})\end{array}$ & $\begin{array}{c}\text { Chloride } \\
(\mathrm{mg} / \mathrm{l})\end{array}$ & $\begin{array}{c}\text { Sulphate } \\
(\mathrm{mg} / \mathrm{l})\end{array}$ & $\begin{array}{c}\text { Bicarbonate } \\
(\mathrm{mg} / \mathrm{l})\end{array}$ \\
\hline 1 & 0.2 & 1.14 & 15.9 & 411 & 245 \\
2 & 0.2 & 0.9 & 5.63 & 317 & 163 \\
3 & 0.2 & 2.15 & 12.8 & 503 & 292 \\
4 & 0.1 & 2.2 & 8.39 & 533 & 176 \\
5 & 0.2 & 0.41 & 13.5 & 169 & 104 \\
6 & 0.1 & 1.8 & 3.55 & 96 & 62 \\
7 & 0.2 & 0.91 & 11.2 & 284 & 46 \\
8 & 0.2 & 0.98 & 10.9 & 208 & 87 \\
\hline
\end{tabular}

Table 4. In situ water sample data from 8 sampling locations within the study area in 2011 showing cation content.

\begin{tabular}{ccccccc}
\hline $\begin{array}{c}\text { Site } \\
\text { number }\end{array}$ & $\begin{array}{c}\text { Calcium } \\
(\mathrm{mg} / \mathrm{l})\end{array}$ & $\begin{array}{c}\text { Iron } \\
(\mathrm{mg} / \mathrm{l})\end{array}$ & $\begin{array}{c}\text { Magnesium } \\
(\mathrm{mg} / \mathrm{l})\end{array}$ & $\begin{array}{c}\text { Manganese } \\
(\mathrm{mg} / \mathrm{l})\end{array}$ & $\begin{array}{c}\text { Potassium } \\
(\mathrm{mg} / \mathrm{l})\end{array}$ & $\begin{array}{c}\text { Sodium } \\
(\mathrm{mg} / \mathrm{l})\end{array}$ \\
\hline 1 & 77.6 & 0.02 & 67.9 & 0.042 & 17.7 & 73.8 \\
2 & 61.1 & 0.228 & 44.5 & 0.03 & 10.4 & 59.8 \\
3 & 86.9 & 0.055 & 67 & 0.087 & 12.4 & 121 \\
4 & 41.1 & 0.316 & 20.3 & 0.135 & 8.13 & 50.8 \\
5 & 37.8 & 0.02 & 27.2 & 0.351 & 8.07 & 33.8 \\
6 & 52.9 & 0.02 & 31.9 & 0.09 & 15 & 12.5 \\
7 & 73 & 0.035 & 48.3 & 0.095 & 11.8 & 60.4 \\
8 & 62.1 & 0.02 & 37.7 & 0.425 & 12.2 & 53.4 \\
\hline
\end{tabular}

Table 5. (a) Comparison of year-wise water quality data for the Pipestem Creek outlet at Pingree in North Dakota, USA. (b) Comparison of year-wise water quality data for the Pipestem Creek outlet at Pingree in North Dakota, USA.

(a)

\begin{tabular}{cccc}
\hline Year & $\mathrm{N}(\mathrm{mg} / \mathrm{l})$ & Phosphate $(\mathrm{mg} / \mathrm{l})$ & Sulphate $(\mathrm{mg} / \mathrm{l})$ \\
\hline 2013 & 0.03 & 0.121 & 573 \\
2014 & 0.016 & 0.172 & 802 \\
2015 & 0.33 & 0.07 & 408 \\
2016 & 0.12 & 0.09 & 612 \\
\hline
\end{tabular}

(b)

\begin{tabular}{ccccccccc}
\hline Year & $\begin{array}{c}\text { Bicarbonate } \\
(\mathrm{mg} / \mathrm{l})\end{array}$ & $\begin{array}{c}\text { Calcium } \\
(\mathrm{mg} / \mathrm{l})\end{array}$ & $\begin{array}{c}\text { Sodium } \\
(\mathrm{mg} / \mathrm{l})\end{array}$ & $\begin{array}{c}\text { Potassium } \\
(\mathrm{mg} / \mathrm{l})\end{array}$ & $\begin{array}{c}\text { Manganese } \\
(\mathrm{mg} / \mathrm{l})\end{array}$ & $\begin{array}{c}\text { Magnesium } \\
(\mathrm{mg} / \mathrm{l})\end{array}$ & $\begin{array}{c}\text { TDS } \\
(\mathrm{mg} / \mathrm{l})\end{array}$ & $\begin{array}{c}\text { TH } \\
(\mathrm{mg} / \mathrm{l})\end{array}$ \\
\hline 2013 & 337 & 125 & 115 & 13.9 & 138 & 71.4 & 1130 & 689 \\
2014 & 826 & 232 & 206 & 16.8 & 270 & 97.1 & 1870 & 1130 \\
2015 & 619 & 146 & 122 & 9.61 & 575 & 69.9 & 1110 & 678 \\
2016 & 543 & 167 & 143 & 11.4 & 256 & 121 & 1340 & 817 \\
\hline
\end{tabular}


clarity, harm wildlife and reduce recreational uses [33]. Decaying algae decreases dissolved oxygen concentration making the streams and lakes unable to support fish and other aquatic life [33]. A higher concentration of Total Dissolved solids (TDS) is noted along with Total Hardness (TH) and Total Alkalinity (TA) (Table 1). Field data from 2011 and USGS field data from 2013 to 2016 from Pingree in North Dakota were compared which produced extremely high levels of TDS ranging from $1130 \mathrm{mg} / \mathrm{L}$ to 1340 $\mathrm{mg} / \mathrm{L}$ along with Total Hardness ranging from $618 \mathrm{mg} / \mathrm{L}$ to $1130 \mathrm{mg} / \mathrm{L}$. The EPA Secondary Regulations advise a maximum contamination level (MCL) of $500 \mathrm{mg} / \mathrm{L}$ for TDS [34]. Generally, high levels of TDS are caused by the presence of potassium, chlorides and sodium which is evident from the data collected within the Pipestem Creek. Sulphate salts are a major contaminant in natural waters. Results from the field data have shown that sulphate content in the watershed is very high. Problems caused by sulphates are most often related to their ability to form strong acids which changes the $\mathrm{pH}$ [35]. Sulphate ions also are involved in complexing precipitation reactions which affect solubility of metals and other substances [35]. High sodium concentrations found in water samples indicate a high $\mathrm{pH}$, lack of oxygen inadequate nutrients in the water. This region has noticeable excessive algal bloom. High levels of bicarbonate were found which may have increased the Sodium Adsorption Ratio (SAR) Index of the water. The SAR is a ratio that measures the relative concentration of sodium to calcium and Magnesium. This index is indicative of the alkalizing effect within the watershed [36]. The FAO Document Repository states that excessive sodium in water promotes soil dispersion and structural breakdown which can result in water infiltration problems due to soil dispersion and plugging and sealing of the surface pores similar to water with low alkalinity [37]. Intensive agricultural activities impact ecological and environmental quality and affect water quality [38]. One of the most significant impacts is from increased Non-Point Source pollution loading, which has caused serious water pollution problems in recent decades [39]. Soil samples analyzed generated similar results showing that the soil was excessively alkaline with presence of large amounts of soluble salts. These may be the effects of landuse which include irrigation patterns such as using excess salts on agricultural fields or use of excessive fertilizers. This watershed can be termed as impaired owing to the fact that it is a source of non-point source pollution resulting from the extensive agricultural fields [39]. The surface geology of this region is basically composed of glacial till which is mostly clay, naturally occurring aluminium silicate [40]. Clay imparts plasticity and is relatively impermeable to water making this region aptly facilitate surface runoff, letting nutrients to flow into the stream.

\subsection{Comparison to a Distributed Model}

The Annualized Agricultural Non-Point Source Model (AnnAGNPS) is used to evaluate non-point source pollution in impaired watersheds. It is currently used by many USA agencies to investigate non-point source pollution problems. The distributed parameter feature of the model allows spatial simulation [41]. Pease et al. (2010) used the AnnAGNPS model to determine the nutrient status of the Pipestem Creek in North Dakota, USA [41]. It was also used to predict the total runoff. The effectiveness of the 
model relies on the fact that it could only be effectively applied for a large agricultural watershed. Runoff predicted by the AnnAGNPS model for the Pipestem creek watershed between 2004 and 2006 showed a coefficient value of 3.17. This relatively low coefficient value indicated that the AnnAGNPS model predicted runoff from the watershed satisfactorily [41]. To further validate the present study, the AnnAGNPS model which is a distributed model was compared to our spatial model in predicting impaired areas within the watershed. A Boolean "And" operation was executed using 3D Analyst in ArcMap 10.4.1. The mathematical operation generated an output value of 1 , if both the input values were found true. The average annual sediment load data from the AnnAGNPS model was combined with the $I_{\mathrm{APCW}}$ score data to generate a new raster dataset. The new dataset was clipped in ArcMap so that the image showed the same areal extent used in the AnnAGNPS model. Figure 11 shows the resultant image where areas of high sediment load overlap with a low $I_{\mathrm{APCW}}$. The data was sorted into a frequency distribution table where the class interval was kept 3 for the first two classes. This was done to create a comparison scale between $I_{\mathrm{APCW}}$ and sediment load within the area that categorises the sediment load into high, moderate and low regions. Within the Pipestem Creek, areas yielding less cropland correspond to areas with increased sediment load. Sediment predicted by the AnnAGNPS model showed limited values, but comparing average annual sediment loads to the landuse data layer, it appeared that non-cropland areas did not significantly contribute to any sediment loads. The spatial distribution generated by the AnnAGNPS study showed fallow areas produce significant amounts of sediment loads from the watershed. These same locations in this study

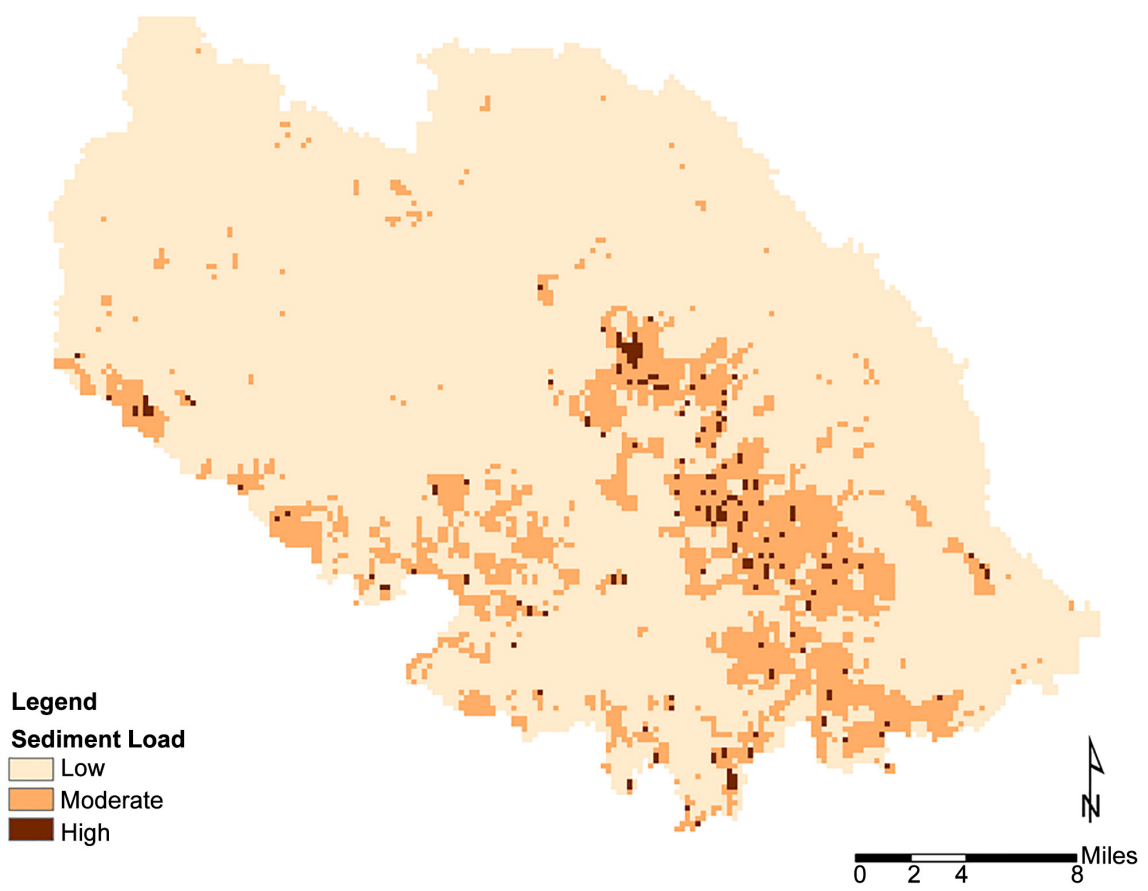

Figure 11. Comparative study: Pipestem Creek watershed showing highlighted areas of increased average annual sediment load. 
generated a low $I_{\mathrm{APCW}}$. Nitrogen and Phosphorus levels were not compared since the model predicted low nutrient levels due to surface runoff. AnnAGNPS is a distributed model which uses explicit data thus it is not compatible with small watersheds [42].

\section{Conclusions}

The levels of TDS are much higher in the data of years 2014 to 2016 compared to the year 2011 which points out to the fact that the alkalizing effect within the watershed had increased.

The goal of the study was used to identify NPS Pollution areas under limited data conditions which may be practical and credible.

Considering the costs incurred and time constraints in monitoring a watershed, this method provides a cost effective preliminary way to identify impairment within a small agricultural watershed such as the Pipestem Creek.

This paper combined geographic and anthropogenic variables to locate impaired areas within a watershed. We can adduce that the method employed in this study can be applied to a small watershed albeit the model is limited to data type and does not take into account a temporal component.

The fusion of real time data within ArcGIS environment has improved the reliability of the index of the ability to produce clean water output, and extended existing GIS functionalities. The implementation of the tool enables decision makers to follow a comprehensive yet easy-to-use procedure to examine weight sensitivity in both criteria and geographic space. The Pipestem reservoir is listed as a Total Maximum Daily Load (TMDL) for nutrients and eutrophication. Conservation practices that can be used to address these water quality issues include grazing management, erosion control, nutrient and pest management, as well as, agricultural waste management, and riparian buffers.

\section{Acknowledgements}

This research was supported by US Forest Service, award \#13-DG-11010000-004, and CFDA Cooperative Forestry Assistance, CFDA Number 10.664, award year FY 2013. The research was carried out in a facility that was funded by NSF EAR Division of Earth Sciences Award \#: 0963486. This work was conducted at the NDSU Environmental Geomechanics Research Facility.

\section{References}

[1] Mohammadi, M., Sheikh, V. and Saddodin, A. (2013) Development and Application of the GFHM Distributed Hydrologic Model for Flood Hydrograph Modelling. Case Study: The Jafarabad Watershed, Golestan Province, Iran.

[2] Sekar, I. and Randhir, T.O. (2007) Spatial Assessment of Conjunctive Water Harvesting Potentialin Watershed Systems. Journal of Hydrology, 334, 39-52.

https:/doi.org/10.1016/j.jhydrol.2006.09.024

[3] Pelorosso, R., Leone, A. and Boccia, L. (2009) Land cover and Land Use Change in the Italian Central Apennines: A Comparison of Assessment Methods. Applied Geography, 29, 35 - 


\section{8. https:/doi.org/10.1016/j.apgeog.2008.07.003}

[4] Jansen, L.J. and Di Gregorio, A. (2002) Parametric land Cover and Land-Use Classifications as Tools for Environmental Change Detection. Agriculture, Ecosystems \& Environment, 91, 89-100. https:/doi.org/10.1016/S0167-8809(01)00243-2

[5] Bender, O., Boehmer, H.J., Jens, D. and Schumacher, K.P. (2005) Analysis of Land-Use Change in Asector of Upper Franconia (Bavaria, Germany) since 1850 Using Land Register Records. Landscape Ecology, 20, 149-163. https:/doi.org/10.1007/s10980-003-1506-7

[6] Mendoza, M.E., Granados, E.L., Geneletti, D., Pérez-Salicrup, D.R. and Salinas, V. (2011) Analysing Land Cover and Land Use Change Processes at Watershed Level: A Multitemporal Study in the Lake Cuitzeo Watershed, Mexico (1975-2003). Applied Geography, 31, 237250. https:/doi.org/10.1016/j.apgeog.2010.05.010

[7] Xiao, J., Shen, Y., Ge, J., Tateishi, R., Tang, C., Liang, Y. and Huang, Z. (2006) Evaluating Urban Expansion and Land Use Change in Shijiazhuang, China, by Using GIS and Remote Sensing. Landscape and Urban Planning, 75, 69-80.

https:/doi.org/10.1016/j.landurbplan.2004.12.005

[8] Turner, M.G., O’Neill, R.V., Gardner, R.H. and Milne, B.T. (1989) Effects of Changing Spatial Scale on the Analysis of Landscape Pattern. Landscape Ecology, 3, 153-162. https:/doi.org/10.1007/BF00131534

[9] Jensen, J.R. (2009) Remote Sensing of the Environment: An Earth Resource Perspective, 2nd Edition, Pearson Education India, New Delhi, 613 p.

[10] Madurapperuma, B., Rozario, P., Oduor, P. and Kotchman, L. (2015) Land-Use and LandCover Change Detection in Pipestem Creek Watershed, North Dakota. International Journal of Geomatics and Geosciences, 5, 416-426.

[11] Osborne, L.L. and Wiley, M.J. (1988) Empirical Relationships between Land Use/Cover and Stream Water Quality in an Agricultural Watershed. Journal of Environmental Management, 26, 9-27.

[12] Soranno, P.A., Hubler, S.L., Carpenter, S.R. and Lathrop, R.C. (1996) Phosphorus Loads to Surface Waters: A Simple Model to Account for spatial Pattern of Land Use. Ecological Applications, 6, 865-878. https:/doi.org/10.2307/2269490

[13] Leh, M., Bajwa, S. and Chaubey, I. (2013) Impact of Land Use Change on Erosion Risk: An Integrated Remote Sensing, Geographic Information System and Modeling Methodology. Land Degradation \& Development, 24, 409-421. https:/doi.org/10.1002/ldr.1137

[14] Chin, A. (2006) Urban Transformation of River Landscapes in a Global Context. Geomorphology, 79, 460-487. https:/doi.org/10.1016/j.geomorph.2006.06.033

[15] Fei, Z., Tiyip, T., Kung, H. and Jianli, D. (2010) The Change of Land Use/Cover and Characteristics of Landscape Pattern in Arid Areas Oasis: An Application in Jinghe, Xinjiang. Geo-Spatial Information Science, 13, 174-185. https:/doi.org/10.1007/s11806-010-0322-x

[16] Iqbal, M.F. and Khan, I.A. (2014) Spatiotemporal Land Use Land Cover Change Analysis and Erosion Risk Mapping of Azad Jammu and Kashmir, Pakistan. The Egyptian Journal of Remote Sensing and Space Science, 17, 209-229. https:/doi.org/10.1016/j.ejrs.2014.09.004

[17] Ceballos-Silva, A. and Lopez-Blanco, J. (2003) Delineation of Suitable Areas for Crops Using a Multi-Criteria Evaluation Approach and Land Use/Cover Mapping: A Case Study in Central Mexico. Agricultural Systems, 77, 117-136. https:/doi.org/10.1016/S0308-521X(02)00103-8

[18] Kollias, V.J. and Kalivas, D.P. (1998) The Enhancement of a Commercial Geographical Information System (ARC/INFO) with Fuzzy Processing Capabilities for the Evaluation of Land Resources. Computers and Electronics in Agriculture, 20, 79-95. 
https:/doi.org/10.1016/S0168-1699(98)00010-6

[19] Chen, Y.C., Lien, H.P. and Tzeng, G.H. (2010) Measures and Evaluation for Environment Watershed Plans Using a Novel Hybrid MCDM Model. Expert Systems with Applications, 37, 926-938. https:/doi.org/10.1016/j.eswa.2009.04.068

[20] Davis, M.L. and Masten, S.J. (2004) Principles of Environmental Engineering and Science. McGraw-Hill, New York, 704.

[21] Ritter, W.F. and Shirmohammadi, A. (Eds.) (2000) Agricultural Nonpoint Source Pollution: Watershed Management and Hydrology. CRC Press, Boca Raton.

[22] NRCS (2007) SSURGO Data Layers. http://websoilsurvey.sc.egov.usda.gov/App/HomePage.htm

[23] Anderson, J.R. (1976) A Land Use and Land Cover Classification System for Use with Remote Sensor Data. Vol. 964, US Government Printing Office.

[24] Barnes, M., Todd, A., Lilja, R.W. and Barten, P. (2009) Forests, Water and People: Drinking Water Supply and Forest Lands in the Northeast and Midwest United States.

[25] Station, M.A.E. (1998) Recommended Chemical Soil Test Procedures for the North Central Region. North Central Regional Research Publication No. 221.

[26] Pfaff, J.D. (1993) Method 300.0 Determination of Inorganic Anions by Ion Chromatography. US Environmental Protection Agency, Office of Research and Development, Environmental Monitoring Systems Laboratory.

[27] Martin, T.D., Brockhoff, C.A., Creed, J.T. and Long, S.E. (1992) Determination of Metals and Trace Elements in Water and Wastes by Inductively Coupled Plasma-Atomic Emission Spectrometry. In: Smoley, KC., Eds., Methods for the Determination of Metals in Environmental Samples, CRC Press Inc., Boca Raton, 33-91.

[28] American Public Health Association, American Water Works Association, Water Pollution Control Federation and Water Environment Federation (1915) Standard Methods for the Examination of Water and Wastewater. Vol. 2.

[29] Brown, E., Skougstad, M.W. and Fishman, M.J. (1970) Methods for Collection and Analysis of Water Samples for Dissolved Minerals and Gases. No. 05-A1, US Government Printing Office.

[30] Weidner, E. and Todd, A. (2011) From the Forest to the Faucet: Drinking Water and Forests in the US. Methods Paper, USDA Forest Service, Washington DC.

[31] Xia, Y., Ti, C., She, D. and Yan, X. (2016) Linking River Nutrient Concentrations to Land Use and Rainfall in a Paddy Agriculture-Urban Area Gradient Watershed in Southeast China. Science of the Total Environment, 566-567, 1094-1105.

https:/doi.org/10.1016/j.scitotenv.2016.05.134

[32] Chislock, M.F., Doster, E., Zitomer, R.A. and Wilson, A.E. (2013) Eutrophication: Causes, Consequences, and Controls in Aquatic Ecosystems. Nature Education Knowledge, 4, 10.

[33] Carpenter, S.R., Caraco, N.F., Correll, D.L., Howarth, R.W., Sharpley, A.N. and Smith, V.H. (1998) Nonpoint Pollution of Surface Waters with Phosphorus and Nitrogen. Ecological Applications, 8, 559-568. https://doi.org/10.1890/1051-0761(1998)008[0559:NPOSWW]2.0.CO;2

[34] Regulations, S.D.W. (2012) Guidance for Nuisance Chemicals. EPA.gov.

[35] DeZuane, J. (1997) Handbook of Drinking Water Quality. John Wiley \& Sons, Hoboken.

[36] Clark, M.L. and Mason, J.P. (2006) Water-Quality Characteristics, Including Sodium-Adsorption Ratios, for Four Sites in the Powder River Drainage Basin, Wyoming and Montana, Water Years 2001-2004. No. 2006-5113. 
[37] Ayers, R.S. and Westcot, D.W. (1985) Water Quality for Agriculture. Vol. 29, Food and Agriculture Organization of the United Nations, Rome.

[38] Hosono, T., Nakano, T., Igeta, A., Tayasu, I., Tanaka, T. and Yachi, S. (2007) Impact of Fertilizer on a Small Watershed of Lake Biwa: Use of Sulfur and Strontium Isotopes in Environmental Diagnosis. Science of the Total Environment, 384, 342-354.

https:/doi.org/10.1016/j.scitotenv.2007.05.033

[39] Ouyang, W., Jiao, W., Li, X., Giubilato, E. and Critto, A. (2016) Long-Term Agricultural Non-Point Source Pollution Loading Dynamics and Correlation with Outlet Sediment Geochemistry. Journal of Hydrology, 540, 379-385.

https:/doi.org/10.1016/j.jhydrol.2016.06.043

[40] NRCS (2005) SSURGO Data Layers. https://www.nrcs.usda.gov/wps/portal/nrcs/detail/soils/survey/?cid=nrcs142p2 053627

[41] Pease, L.M., Oduor, P. and Padmanabhan, G. (2010) Estimating Sediment, Nitrogen, and Phosphorous Loads from the Pipestem Creek Watershed, North Dakota, Using AnnAGNPS. Computers \& Geosciences, 36, 282-291. https:/doi.org/10.1016/j.cageo.2009.07.004

[42] Yu, X., Bhatt, G., Duffy, C. and Shi, Y. (2013) Parameterization for Distributed Watershed Modeling Using National Data and Evolutionary Algorithm. Computers \& Geosciences, 58, 80-90. https:/doi.org/10.1016/j.cageo.2013.04.025

\section{Submit or recommend next manuscript to SCIRP and we will provide best service for you:}

Accepting pre-submission inquiries through Email, Facebook, LinkedIn, Twitter, etc.

A wide selection of journals (inclusive of 9 subjects, more than 200 journals)

Providing 24-hour high-quality service

User-friendly online submission system

Fair and swift peer-review system

Efficient typesetting and proofreading procedure

Display of the result of downloads and visits, as well as the number of cited articles

Maximum dissemination of your research work

Submit your manuscript at: http://papersubmission.scirp.org/

Or contact jgis@scirp.org 